\title{
Burnout syndrome should not be underestimated
}

\author{
DYılmaz Güler ${ }^{1}$ \\ (D) Serkan Şengül1 \\ (iD) Hasan Çaliş ${ }^{1}$ \\ Zülfikar Karabulut ${ }^{2}$
}

1. Assistant Professor, Alanya Alaaddin Keykubat University Medical Faculty, Department of General Surgery, Antalya, Turkey 2. Associate Professor, Alanya Alaaddin Keykubat University Medical Faculty, Department of General Surgery, Antalya, Turkey

http://dx.doi.org/10.1590/1806-9282.65.11.1356

\begin{abstract}
SUMMARY
OBJECTIVES: Burnout syndrome can be seen among health professionals at every stage of their careers. The incidence of burnout syndrome among health care professionals has increased in recent years and varies between countries and depending on different areas of specialization and work units. It is known that burnout syndrome significantly affects the work and social life of individuals. We aimed to investigate the effect of burnout syndrome on trauma and infection.
\end{abstract}

METHODS: The study was conducted in the Alanya Alaaddin Keykubat University, Faculty of Medicine, Training and Research Hospital. All health professionals working at the hospital were included in the study. The Maslach Burnout Inventory was applied to the participants, who were asked about infective disease and trauma history over the past year.

RESULTS: The total burnout rate was $77.8 \%$ among participants. We found that the rate of trauma and infective disease history was significantly high in employees who had burnout syndrome $(p<0.05)$.

CONCLUSION: Burnout syndrome is a common and important problem among health professionals that also has adverse effects on people's daily life, especially increasing the incidence of infection and trauma.

KEYWORDS: Burnout, Professional. Occupational Diseases. Occupational Health. Wounds and Injuries. Infection.

\section{INTRODUCTION}

Burnout syndrome (BOS) was first described by Freudenberger in 1974 and is defined as the response to long-term stress due to the unfavorable working conditions of the workplace'. Burnout was defined by Maslach as a symptom of physical and psychological dimensions, including negative attitudes towards work, life, and other people, which are the result of exhaustion, fatigue, despair, and hopelessness in individuals ${ }^{2}$. Burnout syndrome can affect employees in all sectors ${ }^{1,3}$.

BOS can be seen among health professionals at every stage of their careers ${ }^{4}$. The incidence of BOS among health care professionals varies among countries, ranging from $25 \%$ to $75 \%$, depending on different areas of specialization and work units. Studies conducted on nurses and assistant health personnel have provided BOS rates of approximately $30-50 \%$. The frequency of BOS among doctors varies depending on the branches and the work units ${ }^{5}$.

Although there are different models developed for BOS, the most commonly used model is the one developed by Maslach ${ }^{2,6}$. In it, burnout is generally described as insensitivity towards other persons, feeling of emotional exhaustion, and a decrease in personal competence and in the sense of achievement in the 
professionals who work closely with people. According to this model, there are three different subdimensions of burnout: emotional exhaustion, depersonalization, and a reduced sense of achievement ${ }^{4}$. The Maslach Burnout Inventory (MBI) is accepted as the gold standard in determining the severity and risk of burnout ${ }^{4}$.

\section{METHODS}

The study was conducted between February 2018 and March 2018 in Alanya Alaaddin Keykubat University, Faculty of Medicine, Training and Research Hospital. All of the health professionals working at the hospital were included in the study. In the questionnaire, participants were asked about their sociodemographic characteristics, such as age, gender, and marital status, as well as the units in which they worked, their working patterns (night, daytime, shifts), and total working time. The $\mathrm{MBI}^{2}$ was applied to the participants, and all participants completed the adapted MBI translated into Turkish in $1992^{7}$. In addition, participants were asked about the frequency of infection (upper respiratory tract infection, soft tissue infection, otitis, urinary tract infection, among others) that had been treated in outpatient settings in the past year, and their incidence (1-3, 4-6, 7-10 and >10). Infection incidence of 4-6 and above was considered significant. Participants were also questioned about severe infections (i.e., pneumonia, pyelonephritis, bronchitis, cholecystitis) requiring hospitalization within the last year and all types of trauma, including small domestic traumas such as falls, minor traffic accidents, and home accidents in the past year. At least one or more severe infections and exposures to trauma were considered significant. Employees who were diagnosed with any psychiatric disease or treatment were excluded from the study.

\section{Maslach Burnout Inventory and Assessment}

Participants in the study were given the MBI, which has been widely used for BOS and described by Maslach and Jackson in $1981^{2}$. This scale, consisting of 22 items, assesses burnout in three subdimensions: emotional exhaustion (EE), depersonalization (DP), and personal accomplishment (PA).

The EE subscale has eight questions about fatigue, frustration, and reduced emotional energy. Items 1 , $2,3,6,8,13,16$, and 20 are intended to measure this dimension. The DP subscale describes how an individual behaves in an emotionally deprived way towards those for whom he/she provides care and service. There are six questions (items 5, 10, 11, 15, 21, and 22) on the subscale of DP. The PA subscale describes the situation in which a person feels himself or herself to be sufficient and successful. This scale consists of 8 questions and includes items 4, 7, 9, 12, 14, 17, 18, and 19.

\section{Scoring the Maslach Burnout Inventory}

Subscale scores were obtained with the MBI, which consists of three subscales: EE, DP, and PA. EE and DP subscales were scored from 1 to 5 for each item (1 point: never, 5 points: always). In our study, as in many studies on this subject, scores for each question were added up; the higher the EE and DP subscales scores and the lower the PA subscale scores, the more severe is the burnout syndrome11. In this study, taking into account the maximum score that could be obtained from the scale, participants were assigned to three groups: low, medium, and high burnout. The minimum points were subtracted from the maximum points that could be scored on the subscales, and the cut-off points were calculated by dividing this by three. For the EE subscale, scores of 30 and above were accepted as burnout; scores between 19-29 were accepted as moderate; and scores of 8-18 were accepted as low. In the DP subscale, scores of 23 and above were accepted as burnout; scores between 15-22 were accepted as moderate; and scores of 6-14 were accepted as low. In the PA subscale, scores between 8 and 18 were accepted as burnout; scores between 19 and 29 were accepted as moderate burnout; and scores 30 and above were accepted as low burnout ${ }^{12}$.

\section{Statistical Analysis}

Mean, standard deviation, median lowest, highest, frequency, and ratio values were used in the descriptive statistics of the data. The distribution of the variables was measured by the Kolmogorov-Smirnov test. The Kruskal-Wallis and Mann-Whitney tests were used in the analysis of independent quantitative data. The Chi-square test was used for analyzing independent qualitative data, and Fisher's test was used when Chi-square test conditions were not met. The Spearman correlation analysis was used for correlation analysis. SPSS 22.0 program was used in the analyses.

\section{RESULTS}

A total of 258 respondents were included in the study; 26 were excluded due to missing sociodemographic information or incomplete answers, and the 
calculation was made from the data obtained from a total of 232 participants. The mean age of the participants was 38 years (mean $\pm \mathrm{SD}=37.4 \pm 7.8$ ). The sex distribution was $68.5 \%$ female $(\mathrm{n}=159)$ and $31.5 \%$ male $(\mathrm{n}=73)$. The results of the sociodemographic and hospital work characteristics of the participants are presented in Table 1.

The mean levels of decrease in personal achievement were found to be high in $97.8 \%(n=227)$ and moderate in $2.2 \%(n=5)$ of participants; mean levels of EE were high in $15.1 \%(n=35)$ and moderate in $40.5 \%(n=94)$. The mean levels of DP were high in $73.7 \%(n=171)$ and moderate in $20.7 \%(n=48)$ of participants. The total burnout rate was $77.8 \%$ in our study; there was no significant $(p>0.05)$ correlation between age, the total duration of work, and the duration of work at the current site with EE, DP, and reduced PA.

EE, DP, and reduced PA test scores were not significantly different in men and women ( $p>0.05)$. The incidence of hospitalization due to infective disease in the last year did not differ significantly in women and men ( $>0.05)$. However, the incidence of infectious disease was significantly higher among women in the last year than among men $(\mathrm{p}<0.05)$.

EE, DP, and reduced PA scores did not significantly differ between single and married women ( $p>0.05)$. The incidence of infectious disease and hospitalization for infectious disease in the last year did not differ significantly between single and married participants ( $>0.05)$. However, the rate of trauma history in the last year was significantly higher $(p<0.05)$ in single women than in married women.

EE, DP, and reduced PA scores were not significantly different in the non-NICU and NICU services

TABLE 1. DISTRIBUTION OF PARTICIPANTS ACCORDING TO THEIR SOCIODEMOGRAPHIC CHARACTERISTICS AND WORKING PATTERNS

\begin{tabular}{|c|c|c|c|c|}
\hline & & $\begin{array}{l}\text { Minimum- } \\
\text { Maximum }\end{array}$ & Median & 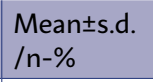 \\
\hline Age & & $20-66$ & 38 & $37,4 \pm 7,8$ \\
\hline Gender & $\begin{array}{l}\text { Female } \\
\text { Male }\end{array}$ & & & $\begin{array}{l}159-68,5 \% \\
73-31,5 \%\end{array}$ \\
\hline Marital Status & $\begin{array}{l}\text { Single } \\
\text { Married }\end{array}$ & & & $\begin{array}{l}73-31,5 \% \\
159-68,5 \%\end{array}$ \\
\hline $\begin{array}{l}\text { Duration of } \\
\text { employment }\end{array}$ & $\begin{array}{l}\text { Total } \\
\text { Current site }\end{array}$ & $\begin{array}{l}1.0-37.0 \\
0.1-20.0\end{array}$ & $\begin{array}{l}14.0 \\
4.0 \\
\end{array}$ & $\begin{array}{l}14,7 \pm 7,6 \\
5,2 \pm 4,0\end{array}$ \\
\hline $\begin{array}{l}\text { Working } \\
\text { pattern }\end{array}$ & Only night & & & $\begin{array}{l}115-49.6 \% \\
57-\% 24.6 \\
60-\% 25.9\end{array}$ \\
\hline Department & $\begin{array}{l}\text { ICU } \\
\text { Non ICU }\end{array}$ & & & $\begin{array}{l}152-\% 65.5 \\
80-\% 34,5\end{array}$ \\
\hline
\end{tabular}

( $>0.05$ ). The rates of hospitalization due to infectious disease and trauma in the last year did not show any significant difference ( $p>0.05)$. However, the incidence of infectious disease in the last year was significantly higher in the ICU workers than in the non-ICU employees $(p<0.05)$.

According to working patterns' DP score, rates of hospitalization due to infectious disease and trauma in the last year did not show any significant difference ( $p>0.05)$. EE and reduced PA scores were higher in the night shift and night on-call working group than in the daytime-only group. $(p<0.05)$ However, EE and reduced PA scores did not differ significantly between the night shift and night on-call working group ( $p>0.05)$.

The EE and DP scores were significantly higher in the group who experienced trauma in last year compared to those who did not $(\mathrm{p}<0.05)$. There was no significant difference in the reduced PA score between the groups with and without trauma in the last year ( $p>0.05)$. The EE and DP scores were significantly higher in the group with a history of infectious disease in the last year than in the group without it $(p<0.05)$. The reduced PA score did not differ significantly between the groups with and without a history of infectious disease in the last year ( $p>0.05)$.

The EE and DP scores were significantly higher in the group with a history of hospitalization due to infectious disease in the last year than in the group without it $(p<0.05)$. The reduced PA score was not significant between the groups with and without a history of hospitalization due to infectious disease in the last year $(\mathrm{p}>0.05)$.

\section{DISCUSSION}

The incidence of BOS in health professionals varies among countries. In a study including 665 general surgeons in the United States in 2014, the frequency of decrease in PA was $16 \%$, EE was $57 \%$, and DP was $50 \%$; burnout syndrome was found to be higher in women than in men (73\% in women, $65 \%$ in men), and no significant relationship was found between marital status and burnout ${ }^{13}$. In a study conducted on 328 GIS surgeons in France in 2013, reduced PA was found in $47 \%$ (severe) and $38.7 \%$ (moderate) of the cases, while EE was present in $24.7 \%$ (severe) and $39.8 \%$ (moderate); DP was seen in $44.6 \%$ (severe) and $35.5 \%$ (moderate). In that study, the incidence of burnout was higher in women (42.5\%); however, there was no significant 
difference in terms of work pattern (night shift or weekly) and marital status ${ }^{14}$. In a study conducted among 370 health professionals in Turkey in 2017, the burnout rate was found to be $61.2 \%$, and no sex or marital status differences were found. However, it was reported that burnout was associated with the profession, duration of employment in the hospital, and educational level ${ }^{15}$. The rate of reduced PA was $21 \%$, EE was $14 \%$, and DP was $4 \%$ in a study conducted among 171 hemodialysis nurses in Turkey in $2016^{\mathbf{1 6}}$. In our study, the rate of severely reduced PA was $97.8 \%$, and the moderate reduction was $2.2 \%$; severe EE was $15.1 \%$, and moderate EE was $40.5 \%$; severe DP was $73.7 \%$, and moderate DP was $20.7 \%$ in 232 health professionals. The remarkable point in the results of our study is that the reduced PA and DP, components of the burnout syndrome, were higher compared to other studies.

The relationship between age and gender and burnout syndrome is controversial ${ }^{13}$. Although many studies have indicated that there is no significant relationship between burnout levels and gender and marital status, the results obtained in these studies are disputed ${ }^{17}$. Examination of 15 studies on burnout reported that there is no relationship between burnout and gender ${ }^{18}$. However, many studies have reported that the frequency of DP is higher in males than in females ${ }^{18,19}$. There are also studies that reported higher BOS rates for women ${ }^{13,14}$. In our study, no statistically significant difference was found between age, gender, and marital status in terms of EE, DP, and reduced PA $(p>0.05)$.

The relationship between the risk of developing BOS and the work pattern has been reported in many studies ${ }^{20}$ It has been emphasized that reducing work time would lead to increased quality of life and, consequently, decreased incidence of BOS $^{21}$. Personnel in emergency and intensive care units are reported to have higher BOS rates than other health professionals. It has been reported that intensive care personnel has higher rates of BOS due to working conditions and high-stress exposure ${ }^{22}$. Emergency room workers are reported to have higher rates of BOS due to various reasons, including stressful working conditions, encountering a wide range of patients and illnesses, and 12 or 24 hours of continuous work because of the shift system ${ }^{23}$. In our study, EE, DP, and reduced PA incidence scores were not significantly different between ICU and non-ICU workers ( $p>0.05)$. EE and reduced PA scores frequency were higher in those who worked night shifts and daytime and night-time on-call group than in the daytime only group $(\mathrm{p}<0.05)$.

It has been reported that BOS and related findings affect the individual's personal experience and individual success; furthermore, factors such as stress in private life and family life play a role in the development of BOS $^{24}$. BOS not only reduces health professionals' success in their work-life but also increases their risks. In a study conducted in the United States, doctors diagnosed with BOS were found to have a higher prevalence of antibiotic prescriptions for acute upper-respiratory-tract infections ${ }^{25}$. In a study conducted in 2015, 333 nurses were surveyed on the relationship between BOS and self-protection against infections and contagious diseases during frequent procedures such as injections. Although there are limited numbers of studies on the subject, it has been reported that as the BOS rate increased, the self-protection index of the employees diminished ${ }^{26}$. Accordingly, in our study, a total of 9 employees were admitted to the hospital due to infectious disease in the last year with different diagnoses (four pneumonia, two bronchitis, one cholecystitis, one gastroenteritis, and one cryptic tonsillitis). In addition, a total of 43 workers had a history of trauma in the last year (16 falls, 12 small house accidents, eight traffic accidents, four bone fractures, two burns, and one soft tissue trauma due to sprain). As a result of the statistical analysis, among the employees who had a history of 4 or more infectious diseases in the last year and those who had required hospitalization due to infectious diseases in the last year, the EE and DP scores were significantly higher than in the group without a history of infectious disease and hospitalization in the last year $(\mathrm{p}<0.05)$. Likewise, EE and DP scores were significantly higher in the employees with a history of trauma in the last year than in employees who had no trauma history in the last year $(p<0.05)$. To our knowledge, there is no other study about the relationship between trauma and infection with BOS in the English literature.

\section{CONCLUSIONS}

Burnout syndrome is a common and important problem among health professionals that also has adverse effects on people's daily life, especially increasing the incidence of infection and trauma. BOS can leads to serious health problems, as shown in our study. This situation also reflects on the health workers' interaction with patients and causes inefficiency in the work place. There is still no systematic approach 
to prevent and treat BOS. More studies should be done to determine the factors leading to BOS, to get an early diagnosis, treatment, and systematic approaches.

\section{Funding}

The authors declare that this article has received no financial support.

\section{Conflict of Interest}

The authors have no conflicts of interest relevant nor financial support for this article

\section{Acknowledgments}

We would like to thank all health care workers in our hospital who participated in the study.

\section{RESUMO}

OBJETIVOS: A Síndrome de Burnout pode ser vista entre os profissionais de saúde em todas as etapas de suas carreiras. A incidência de Síndrome de Burnout entre os profissionais de saúde aumentou nos últimos anos e varia de país para país, dependendo das diferentes áreas de especialização e unidades de trabalho. Sabe-se que a Síndrome de Burnout afeta significativamente o trabalho e a vida social dos indivíduos. Nosso objetivo foi investigar o efeito da Síndrome de Burnout no trauma e na infecção.

MÉTODos: O estudo foi conduzido na Universidade de Alanya Alaaddin Keykubat, Faculdade de Medicina, Hospital de Treinamento e Pesquisa. Todos os profissionais de saúde que trabalham no hospital foram incluídos no estudo. O Maslach Burnout Inventory foi aplicado aos participantes e a história de doença infecciosa e trauma no último ano foi solicitada.

RESULTADOS: A taxa total de Burnout foi de 77,8\% dos participantes. Descobriu-se que a taxa de trauma e história de doença infecciosa foi significativamente alta em funcionários que tinham Síndrome de Burnout $(p<0,05)$.

CONCLUSÃO: A Síndrome de Burnout é um problema comum e importante entre os profissionais de saúde, e essa condição também teve efeitos adversos na vida diária das pessoas, especialmente aumentando a incidência de infecção e trauma.

PALAVRAS-CHAVE: Esgotamento profissional. Doenças profissionais. Saúde do trabalhador. Ferimentos e lesões. Infecção.

\section{REFERENCES}

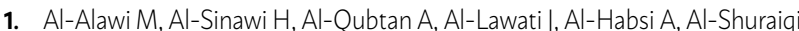
$M$, et al. Prevalence and determinants of burnout syndrome and depression among medical students at Sultan Qaboos University: a cross-sectional analytical study from Oman. Arch Environ Occup Health. 2019;74(3):130-9.

2. Brewer EW, Shapard L. Employee burnout: a meta-analysis of the relationship between age and years of experience. Human Resource Development Review. 2004:3:102-23.

3. Bridgeman PJ, Bridgeman MB, Barone J. Burnout syndrome among healthcare professionals. Am J Health Syst Pharm. 2017;75(3):147-52.

4. Cevik AA, Holliman CI, Yanturali S. Emergency physicians and "burn out" syndrome. Ulus Travma Acil Cerrahi Derg. 2003;9(2):85-9.

5. Chati R, Huet E, Grimberg L, Schwarz L, Tuech IJ, Bridoux V. Factors associated with burnout among French digestive surgeons in training: results of a national survey on 328 residents and fellows. Am J Surg. 2017;213(4):754-62.

6. Colindres CV, Bryce E, Coral-Rosero P, Ramos-Soto RM, Bonilla F, Yassi A. Effect of effort-reward imbalance and burnout on infection control among Ecuadorian nurses. Int Nurs Rev. 2018;65(2):190-9.

7. Ergin C. Doktor ve hemşirelerde tükenmişlik ve Maslach Tükenmişlik Ölçeği'nin uyarlanması. VII. Ulusal Psikoloji Kongresi Bilimsel Çalışmaları, Ankara: Türk Psikologlar Derneği Yayınları;1992. p.143-54.

8. Oliveira GS Jr, Ahmad S, Stock MC, Harter RL, Almeida MD, Fitzgerald $P C$, et al. High incidence of burnout in academic chairpersons of anesthesiology: should we be taking better care of our leaders? Anesthesiology. 2011;114(1):181-93.

9. Donchin $Y$, Seagull FJ. The hostile environment of the intensive care unit. Curr Opin Crit Care. 2002;8(4):316-20.

10. Elmore LC, Jeffe DB, Jin L, Awad MM, Turnbull IR. National survey of burnout among US General Surgery Residents. J Am Coll Surg. 2016;223(3):440-51.

11. Embriaco N, Azoulay E, Barrau K, Kentish N, Pochard F, Loundou A, et al. High level of burnout in intensivists: prevalence and associated factors. Am J Respir Crit Care Med. 2007;175(7):686-92.

12. Fahrenkopf AM, Sectish TC, Barger LK, Sharek PJ, Lewin D, Chiang VW, et al. Rates of medication errors among depressed and burnt out residents: prospective cohort study. BMJ. 2008;336(7642):488-91.

13. Freudenberger HJ. Staff burnout. | Soc Issues. 1974;30:159-65.
14. Golub IS, Weiss PS, Ramesh AK, Ossoff RH, Johns MM 3rd. Burnout in residents of otolaryngology-head and neck surgery: a national inquiry into the health of residency training. Acad Med. 2007;82(6):596-601.

15. Gorgulu $O$, Akilli $A$. The determination of the levels of burnout syndrome, organizational commitment, and job satisfaction of the health workers. Niger J Clin Pract. 2017;20(1):48-56

16. Gulalp B, Karcioglu O, Sari A, Koseoglu Z. Burnout: need help? J Occup Med Toxicol. 2008;5:3:32.

17. Guthrie E, Black D, Bagalkote H, Shaw C, Campbell M, Creed F. Psychological stress and burnout in medical students: a five-year prospective longitudinal study. J R Soc Med. 1998;91(5):237-43.

18. Maslach C. Burnout: the cost of caring. New Jersey: Prentice-Hall; 1982 p.61.

19. Maslach C, Jackson SE. The measurement of experienced burnout. J Occupational Behaviour. 1981;2:99-113.

20. McMurray JE, Linzer M, Konrad TR, Douglas |, Shugerman R, Nelson $K$. The work lives of women physicians results from the physician work life study. The SGIM Career Satisfaction Study Group. I Gen Intern Med. 2000;15(6):372-80

21. Pines AM. Couple burnout: causes and cures. New York \& London. Routledge. 1996. p.286.

22. Poncet MC, Toullic P, Papazian L, Kentish-Barnes N, Timsit JF, Pochard F, et al. Burnout syndrome in critical care nursing staff. Am J Respir Crit Care Med. 2007;175(7):698-704.

23. Shenoi AN, Kalyanaraman M, Pillai A, Raghava PS, Day S. Burnout and Psychological distress among pediatric critical care physicians in the United States. Crit Care Med. 2018;46(1):116-22.

24. Sun BZ, Chaitoff A, Hu B, Neuendorf K, Manne M, Rothberg MB. Empathy, burnout, and antibiotic prescribing for acute respiratory infections: a cross-sectional primary care study in the US. Br | Gen Pract. 2017;67(661):e565-71.

25. Thomas NK. Resident burnout. JAMA. 2004;292(23):2880-9.

26. Thomas H Jr, Schwartz E, Whitehead DC. Eight-versus 12-hours shifts: implications for emergency physicians. Ann Emerg Med. 1994:23(5):1096-100 